\title{
AN EVALUATION OF TECHNICAL REPORT WRITING SYLLABUS AT THE PREPARATORY YEAR PROGRAM
}

\author{
Soada Idris Khan \\ The Preparatory Year Program, Najran University, Najran, King of Saudi Arabia \\ E-mail: khan.soada@gmail.com
}

\begin{abstract}
APA Citation: Khan, S. I. (2018). An evaluation of technical report writing syllabus at the preparatory year program. English Review: Journal of English Education, 7(1), 1-8. doi: 10.25134/erjee.v7i1.1528.
\end{abstract}

Abstract: The current study aims to critically analyze the contents of the Technical Report Writing syllabus as well as identify whether the syllabus meets course objectives or not. The study also suggests some remedies to improve the contents of the syllabus. As part of the study, twenty EFL teachers from Preparatory Year Program were selected for this study. A quantitative questionnaire containing 10 statements was administered to gather data from the participants. In addition, an interview session with a set of 5 questions based on the key elements on the current syllabus was also conducted with the teachers to have their expert opinion and suggestions. The analysis of data revealed that textbook is appropriate for the students and needs not be replaced. However, syllabus should include some more activities that may address to the needs of weak students. The study also suggests teachers to exploit other resources (from internet or library) in order to give an extra push to the learners.

Keywords: course objectives; syllabus analysis; technical report writing.

\section{INTRODUCTION}

Syllabus is a very important document in an academic setting. It usually covers the proposed topics to cover in a semester/academic year. The institution/department provides syllabus as a kind of official and professional document. Moreover, it also works as a personal copy of instructors that are usually kept in their begs to consult the taught and to be taught items. The syllabus is, thus, both a professional document as well as a personal document. It reflects the instructor's feelings, attitudes, and beliefs about the subject matter, teaching, learning, and students, as well as setting out the "nuts and bolts" of the course. When so constructed, the syllabus can serve as a guide to the instructor as much as a guide to the class (Parkes \& Harris, 2002). However, a syllabus is also speculated as a "summary of the content to which learners will be exposed" (Yalden, 1987, p. 87).

A syllabus is often thought of as that apparently benign document instructors assemble and distribute to students at the start of the semester. Whether it is intended or not, the quality of the syllabus is a fairly reliable indicator of the quality of teaching and learning that will take place in a course (Woolcock, 2003).

The process of developing a syllabus can be a reflective exercise, leading the instructor to carefully consider his or her philosophy of teaching, why the course is important, how the course fits in the discipline, as well as what topics will be covered, when assignments will be due, and so on (Eberly, Newton, \& Wiggins, 2001; Grunert, 1997).

A syllabus lets students know what the course is about, why the course is taught, where it is going, and what will be required for them to be successful in the course (Altman \& Cashin, 2003). The welldesigned syllabus provides a solid beginning to the semester, sets the tone for the course, provides a conceptual framework for the course, serves as a "virtual handshake" between the instructor and students, and 


\section{Soada Idris Khan}

An evaluation of technical report writing syllabus at the preparatory year program

becomes a resource that is referred to over the course of the semester. It also shows students to take teaching seriously (Davis, 1993).

The syllabus is usually prepared keeping in mind certain course objectives. The activities, tasks, exercises under different topics are considered parts of syllabus and a replication of course objectives. As syllabus is a very important document and a primary means to carry out the business of teaching in the classroom, it is obligatory to evaluate the contents of the syllabus (from time to time) to ensure it meets course objectives. Course evaluation helps to identify how successfully course objectives were met and what amendments the designer should introduce to achieve better results in the future (Ismagilova \& Polyakova, 2015).

The importance of the needs analyses for syllabus design is indisputable. It acts as terminus a quo for materials selection, assessment criteria and activities that the course will be based on. Many articles were published about this problem by Alderson (1980), Berwick (1989), Brindley (1989), Crocker (1981), and Hawkey (1980). As far as needs analyses definition is concerned, it could vary but it will be based on the learner as the central part of the analyses anyway. Widdowson (1983) distinguishes "goaloriented" and "process-oriented" definition of needs. The key feature of this approach is the importance to evaluate the present language ability of the learner and to recognize the target situation where the learner will use the language. The "goaloriented" definition is correlated to the objectives set while designing the syllabus whereas the "process-oriented" definition relates to pedagogic aims. Language needs of the learner should be the bases for course development. Information on his or her language needs will help in drawing up a profile to establish coherent objectives, and take subsequent decisions on course content (McDonough, 1984).

Now the question is how to evaluate a syllabus based on particular course objectives and who can be good evaluators of the syllabus. Alderson and Waters (1980, 1987) point out four main aspects to consider while developing course evaluation programme: 1) What should be evaluated? 2) How can the course be evaluated? 3) Who should be involved in evaluation? And 4) When (and how often) should evaluation take place? Keeping in mind these four important aspects of evaluation, the present study evaluates the contents of the syllabus of Technical Report Writing at Preparatory Year Program, Najran University. Technical Report Writing course has certain objectives; like, by the end of the course students will be able to:

write a simple and technical paragraph with an effective topic sentence;

support the topic sentence with appropriate details;

take effective notes and write concise summaries;

write a covering letter and CV tailored for a particular job;

write a formal letter for different situations;

write memos and reports for various contexts;

comprehend and use ESP vocabulary for different professional fields.

Questionnaire and interview methods are used to evaluate the contents of the syllabus. Teachers are the main evaluators of the syllabus as they practically use it in the classroom and are well familiar with its effectiveness. Syllabus evaluation should be done periodically, possibly after every new book, is selected and implemented. The present syllabus is in operation for last two semesters. Therefore, it is obligatory to ensure the effectiveness of the syllabus, having evaluated its contents.

Thus, the objectives of this study are to critically analyze the contents of the syllabus, to identify whether the syllabus meets course objectives or not, and to suggest some remedies to improve the contents of the syllabus of Technical Report Writing at PYP, Najran University. 
ENGLISH REVIEW: Journal of English Education Volume 7, Issue 1, December 2018

\section{METHOD}

To ensure the validity of the survey questionnaire, it was first piloted to $10 \mathrm{EFL}$ instructors; their feedback was useful for modifying some items. The survey was also given to four assistant Professors to examine its validity. Some items were modified as per their suggestions to meet the content validity.

Twenty EFL teachers from PYP were selected for this study. Participants' age ranges 28 to 47 years old. Their experience of teaching of English varies between 2-20 years. Most of the participants' experience of teaching Technical Writing course ranges from four years to one semester.

A quantitative questionnaire (containing 10 statements) was administered to gather data from the participants. The aim of the questionnaire was to measure how teachers perceived and rated the current syllabus of Technical Report Writing at PYP. The contents of the questionnaire are based on course objectives, using 5-Point Likertscales of agreement. The researchers circulated the questionnaire to forty participants and thirty were returned. Finally, twenty questionnaires given serious attention were selected as a sample of this study. To interpret the level of means, the authors applied Ariffin and Salbiah's (1996)
p-ISSN 2301-7554, e-ISSN 2541-3643

https://journal.uniku.ac.id/index.php/ERJEE

model of explaining means as it is summarized in Table 1.

In addition, an interview session was also conducted with the teachers to have their expert opinion and suggestions. The interview included 5 key statements on the current syllabus. Twenty teachers teaching Technical Writing were also interviewed and their suggestions and opinions were taken into consideration.

Table1. Score category breakdown adopted from Ariffin and Salbiah (1996)

\begin{tabular}{cc}
\hline Means & Corresponding level \\
\hline $1.0-1.80$ & Very low \\
$1.81-2.60$ & Low \\
$2.61-3.40$ & Moderate \\
$3.41-4.20$ & High \\
$4.21-5.0$ & Very high \\
\hline
\end{tabular}

\section{RESULTS AND DISCUSSION Questionnaire analysis}

Questionnaire is one of the methods used to collect the data. The questionnaire uses 5Point Likert-scales of agreement. Reed (1989) is of the opinion that Likert-type rating scale should be used to generally gather data. Jung, Osterwalder and Wipf (2000) support the Likert scale: "this was the only assessment instrument I found that was practical for the classroom" (p.2). The result of the questionnaire analysis is presented in Table 2 .

Table 2. Descriptive statistics of the survey's statements and result discussion

\begin{tabular}{|c|c|c|c|c|c|c|c|}
\hline $\begin{array}{c}\text { S. } \\
\text { No. } \downarrow\end{array}$ & $\begin{array}{c}\text { Scales } \rightarrow \\
\text { Statements } \downarrow\end{array}$ & $\begin{array}{c}5 \\
\text { Strongly } \\
\text { agree }\end{array}$ & $\begin{array}{c}4 \\
\text { Agree }\end{array}$ & $\begin{array}{c}3 \\
\text { Can't } \\
\text { say }\end{array}$ & $\begin{array}{c}2 \\
\text { Disagree }\end{array}$ & $\begin{array}{c}1 \\
\text { Strongly } \\
\text { disagree }\end{array}$ & Mean \\
\hline 1. & $\begin{array}{l}\text { The textbook enables } \\
\text { students write a simple and } \\
\text { technical paragraph with an } \\
\text { effective topic sentence }\end{array}$ & $\begin{array}{c}0 \\
0 \%\end{array}$ & $\begin{array}{c}11 \\
55 \%\end{array}$ & $\begin{array}{c}9 \\
45 \%\end{array}$ & $\begin{array}{c}0 \\
0 \%\end{array}$ & $\begin{array}{c}0 \\
0 \%\end{array}$ & 3.55 \\
\hline 2. & $\begin{array}{l}\text { The textbook enables } \\
\text { students support the topic } \\
\text { sentence with appropriate } \\
\text { details }\end{array}$ & $\begin{array}{c}0 \\
0 \%\end{array}$ & $\begin{array}{c}16 \\
80 \%\end{array}$ & $\begin{array}{c}4 \\
20 \%\end{array}$ & $\begin{array}{c}0 \\
0 \%\end{array}$ & $\begin{array}{c}0 \\
0 \%\end{array}$ & 3.8 \\
\hline 3. & $\begin{array}{l}\text { The textbook enables } \\
\text { students take effective notes } \\
\text { and write concise summaries }\end{array}$ & $\begin{array}{c}7 \\
35 \%\end{array}$ & $\begin{array}{c}8 \\
40 \%\end{array}$ & $\begin{array}{c}5 \\
25 \%\end{array}$ & $\begin{array}{c}0 \\
0 \%\end{array}$ & $\begin{array}{c}0 \\
0 \%\end{array}$ & 4.1 \\
\hline 4. & $\begin{array}{l}\text { The textbook enables } \\
\text { students write a covering } \\
\text { letter and CV tailored for a } \\
\text { particular job }\end{array}$ & $\begin{array}{c}7 \\
35 \%\end{array}$ & $\begin{array}{c}10 \\
50 \%\end{array}$ & $\begin{array}{c}3 \\
15 \%\end{array}$ & $\begin{array}{c}0 \\
0 \%\end{array}$ & $\begin{array}{c}0 \\
0 \%\end{array}$ & 4.2 \\
\hline 5. & $\begin{array}{l}\text { The textbook enables } \\
\text { students write a formal letter }\end{array}$ & $\begin{array}{c}4 \\
20 \%\end{array}$ & $\begin{array}{c}14 \\
70 \%\end{array}$ & $\begin{array}{c}2 \\
10 \%\end{array}$ & $\begin{array}{c}0 \\
0 \%\end{array}$ & $\begin{array}{c}0 \\
0 \%\end{array}$ & 4.1 \\
\hline
\end{tabular}




\section{Soada Idris Khan}

An evaluation of technical report writing syllabus at the preparatory year program

\begin{tabular}{|c|c|c|c|c|c|c|c|}
\hline & for different situations & & & & & & \\
\hline 6. & $\begin{array}{l}\text { The textbook enables } \\
\text { students write memos and } \\
\text { reports for various contexts }\end{array}$ & $\begin{array}{c}4 \\
20 \%\end{array}$ & $\begin{array}{c}10 \\
50 \%\end{array}$ & $\begin{array}{c}6 \\
30 \%\end{array}$ & $\begin{array}{c}0 \\
0 \%\end{array}$ & $\begin{array}{c}0 \\
0 \%\end{array}$ & 3.9 \\
\hline 7. & $\begin{array}{l}\text { The textbook facilitates } \\
\text { students' writing their } \\
\text { personal blog on everyday } \\
\text { situations and topics }\end{array}$ & $\begin{array}{c}4 \\
20 \%\end{array}$ & $\begin{array}{c}12 \\
60 \%\end{array}$ & $\begin{array}{c}3 \\
15 \%\end{array}$ & $\begin{array}{c}1 \\
5 \%\end{array}$ & $\begin{array}{c}0 \\
0 \%\end{array}$ & 3.95 \\
\hline 8. & $\begin{array}{l}\text { The textbook helps students } \\
\text { comprehend and use ESP } \\
\text { vocabulary for different } \\
\text { professional fields }\end{array}$ & $\begin{array}{c}1 \\
5 \%\end{array}$ & $\begin{array}{c}14 \\
70 \%\end{array}$ & $\begin{array}{c}4 \\
20 \%\end{array}$ & $\begin{array}{c}1 \\
5 \%\end{array}$ & $\begin{array}{c}0 \\
0 \%\end{array}$ & 3.75 \\
\hline 9. & $\begin{array}{l}\text { The textbook enables } \\
\text { students to produce } \\
\text { coherence and cohesion in } \\
\text { their writing pieces }\end{array}$ & $\begin{array}{c}5 \\
25 \%\end{array}$ & $\begin{array}{c}10 \\
50 \%\end{array}$ & $\begin{array}{c}5 \\
25 \%\end{array}$ & $\begin{array}{c}0 \\
0 \%\end{array}$ & $\begin{array}{c}0 \\
0 \%\end{array}$ & 4 \\
\hline 10. & $\begin{array}{l}\text { The textbook enables } \\
\text { students form different types } \\
\text { of complex and compound } \\
\text { sentences independently }\end{array}$ & $\begin{array}{c}4 \\
20 \%\end{array}$ & $\begin{array}{c}13 \\
65 \%\end{array}$ & $\begin{array}{c}3 \\
15 \%\end{array}$ & $\begin{array}{c}0 \\
0 \%\end{array}$ & $\begin{array}{c}0 \\
0 \%\end{array}$ & 4.05 \\
\hline
\end{tabular}

The first statement in the questionnaire 'The textbook enables students write a simple and technical paragraph with an effective topic sentence' reveals that there is none who strongly agreed to the statement. $55 \%$ participants (a majority) felt the textbook enables students write a simple and technical paragraph with an effective topic sentence. $45 \%$ of the participants had no idea. There was none with disagreement. The mean of the statement is 3.55 that lies in the category of 'High' as per the breakdown adopted from the scale of Ariffin and Salbiah (1996).

The second statement in the questionnaire 'The textbook enables students support the topic sentence with appropriate details' displays that there is no one who strongly agreed to the statement. However, $80 \%$ of the participants opined the textbook enables students support the topic sentence with appropriate details. There was none with disagreement. The mean is categorized as high.

The third statement in the questionnaire 'The textbook enables students take effective notes and write concise summaries' shows that there are $35 \%$ of the participants who strongly agreed to the statement. $40 \%$ of the participants are of the opinion that the textbook enables students take effective notes and write concise summaries. $25 \%$ of the participants had no opinion. There was none with disagreement. The mean is high.

The fourth statement in the questionnaire 'The textbook enables students write a covering letter and $C V$ tailored for a particular job' exhibits that $35 \%$ of the participants strongly agreed. There are 50\% of the participants who agreed that the textbook enables students write a covering letter and $C V$ tailored for a particular job. $15 \%$ of the participants had no opinion. There was none with disagreement. The mean is ranked as high.

The fifth statement in the questionnaire 'The textbook enables students write a formal letter for different situations' divulges that there are $20 \%$ of the participants who strongly agreed to the statement that the textbook enables students write a formal letter for different situations. $70 \%$ of the participants agreed with the statement.10\% of the participants did not express their opinion. There was none with disagreement. The mean is high.

The sixth statement in the questionnaire 'The textbook enables students write memos and reports for various contexts' discloses that there are $20 \%$ of the participants who strongly agreed to the statement. $50 \%$ of the participants concurred that the textbook enables students write memos and reports for various contexts. $30 \%$ of the participants 
ENGLISH REVIEW: Journal of English Education Volume 7, Issue 1, December 2018

were not sure about it. There was none with disagreement. The mean is high.

The seventh statement in the questionnaire 'The textbook facilitates students' writing their personal blog on everyday situations and topics' shows that there are $20 \%$ of the participants who strongly agreed to the statement. $60 \%$ of the participants concurred that the textbook facilitates students' writing their personal blog on everyday situations and topics. $15 \%$ of the participants were not sure about it. There were $5 \%$ with disagreement. The mean is high.

The eighth statement in the questionnaire 'The textbook helps students comprehend and use ESP vocabulary for different professional fields' unveils that there are 5\% of the participants with absolute agreement to the statement that the textbook helps students comprehend and use ESP vocabulary for different professional fields. $70 \%$ of the participants agreed, while there $20 \%$ of the participants who did not state an opinion. 5\% of the participants did not agree with the statement. There was none with disagreement. The mean is high.

The ninth statement in the questionnaire 'The textbook enables students to produce coherence and cohesion in their writing pieces' reveals that $25 \%$ of the participants thought that the textbook enables students to produce coherence and cohesion in their writing pieces. $50 \%$ of the participants agreed with the statement though $25 \%$ (a significant percentage) of the participants had no opinion. There was none with disagreement. The mean is high.

The tenth statement in the questionnaire reveals that $20 \%$ of the participants strongly agreed with the statement stating that 'The textbook enables students to form different types of complex and compound sentences independently'. $65 \%$ of the participants agreed to the statement. $15 \%$ had no idea. There was none with disagreement. The mean is high.

The analysis shows that most of the key elements in the syllabus fall in high category. As a result, the prescribed syllabus
p-ISSN 2301-7554, e-ISSN 2541-3643

https://journal.uniku.ac.id/index.php/ERJEE

for PYP is well designed though none of the statement falls in the category of very high. It shows that it does not meet its objectives completely however, they do meet largely. This is also fact that no textbook is perfect. If this syllabus (textbook) is replaced, there is no surety whether another selected book can meet all the course objectives completely or not. According to Grant (1987), "the perfect textbook does not exist, but the best book available for you and your students certainly does" (cited in McGrath 2002, p. 41). The statements of the teachers based on the key elements of syllabus, course objectives, pedagogy, etc. show their satisfactory response. Most of them agree with the statements. It shows that the syllabus is perfect.

Despite the sincere efforts made by the teachers, some of the students are not able to demonstrate a good progress in technical report writing. They still face problems in formal letter writing, CV writing, memos writing, reports writing, etc. The teachers and students should develop a common understanding on what activities should be used in the classroom and what skills they have to develop respectively. As Jung, Osterwalder \& Wipf (2000, p. 5) are of the opinion that "we realized that students needed lessons and activities that would introduce them to the language and terminology associated with the skills they would be expected to learn." As it is technical report writing course, terminology (ESP vocabulary) plays an important role here. Syllabus should include some more activities that may address to the needs of weak students. As for the writing skill, Harmer (1991) suggested the following exercises might be useful: 1) Relaying instructions, 2) Writing reports, 3) Cooperative writing, 4) Exchange letters, and 5) Writing journals.

These kinds of activities (especially cooperative writing and writing journals) may be incorporated into syllabus as syllabus has least exercises to develop these skills. Moreover, other pedagogical issues must be taken into consideration. For example, 


\section{Soada Idris Khan}

An evaluation of technical report writing syllabus at the preparatory year program

teachers should try to engage learners more in writing activities. It is imperative for students to become responsible for their own learning. They need to see themselves as active members of the learning process. Students must be assigned peer evaluation so that they can learn from the mistakes of each other. Through involvement in evaluation, they can see their performance more clearly. They are not victims at the mercy of the teacher's red pen. Instead, they are encouraged to realistically assess their own skills and compare them with others (Jung, Osterwalder \& Wipf, 2000).

\section{Interview analysis}

Another method used to collect the data was interview. Twenty samples were selected out of 30 which were filled in with complete information. The participants responded to the following questions in the interview:

1) Teachers rate (on a scale of 1-5) the students' proficiency in Technical Report Writing.

2) Mention some common learning difficulties students (in teachers' opinion) face during Technical Report Writing class!
3) Mention some pedagogical (teaching) problems teachers face during teaching of Technical Report Writing!

4) Suggestions for improving students' general language proficiency in Technical Report Writing.

5) Is the course designed in accordance to the learner-based approach? Comment briefly!

\section{Table 3. Results of interview question No. 1

\begin{tabular}{ccc}
\hline Q.1. & $\begin{array}{c}\text { Number of } \\
\text { teachers }\end{array}$ & Scale \\
\hline & 2 & 2 \\
& 10 & 3 \\
6 & 4 \\
\hline
\end{tabular}

As shown in the table, in response to the first question, 4 teachers rated the proficiency of the students as 2 on a scale of 3-5. 10 teachers rated students as 3 and 6 other teachers rated as 4. Students' overall proficiency was rated $1-4 \mathrm{~s}$. The scale shows that students' proficiency is good but still needs improvement. Teachers can improve their proficiency by providing them more assignments, classroom learner-cantered activities, essay-writing competition, quiz competition, etc.

Table 4. Results of interview question No. 2

\begin{tabular}{ccc}
\hline Q.2. & $\begin{array}{c}\text { Number of } \\
\text { participants }\end{array}$ & $\begin{array}{c}\text { Some common learning difficulties students (in teachers' opinion) } \\
\text { face during Technical Writing class }\end{array}$ \\
\hline 5 & Inadequate use of audio-visual technologies \\
8 & Complex and compound sentences \\
7 & Connecting related sentences to make a paragraph \\
\hline
\end{tabular}

As shown in Table 4, in response to question number 2, there were varied responses, only common responses were placed in the table. Most of the teachers agreed that students had problems in complex and compound sentences and writing a paragraph. They should be given more practice as writing skill needs a lot of practice.

Table 5. Results of interview question No. 3

\begin{tabular}{ccc}
\hline Q.3 & $\begin{array}{c}\text { Number of } \\
\text { participants }\end{array}$ & $\begin{array}{c}\text { Mention some pedagogical (teaching) problems teachers face } \\
\text { during teaching of Technical Writing }\end{array}$ \\
\hline 5 & Less access to multimedia and equipment \\
8 & Low academic standard of students \\
7 & Students are not motivated \\
\hline
\end{tabular}

As shown in Table 5, in response to question number 3 , there were some common difficulties faced by the teachers. A majority of teachers believe (as shown in 
ENGLISH REVIEW: Journal of English Education Volume 7, Issue 1, December 2018

responses) that students' low academic standard was a serious issue. Moreover, they are not much motivated to improve themselves. Thus, a placement test must be
p-ISSN 2301-7554, e-ISSN 2541-3643

https://journal.uniku.ac.id/index.php/ERJEE

conducted in order to have a filter in admission/selection process of students. Students should be oriented to motivational talks by the experts in this field.

Table 6. Results of interview question No. 4

\begin{tabular}{ccc}
\hline Q.4 & $\begin{array}{c}\text { Number of } \\
\text { participants }\end{array}$ & $\begin{array}{c}\text { Suggestions for improving students' general language } \\
\text { proficiency in Technical Writing }\end{array}$ \\
\hline 4 & More exposure to English activities \\
& Task based exercises \\
& & More resources other than textbook must be provided \\
& Students must be given exposure to target language \\
\hline
\end{tabular}

As shown in Table 6, in response to question number 4, there were some common suggestions proposed by the teachers. The common suggestions were; 1 ) to include more learning resources other than the textbook; 2) students must be exposed to target language, and 3) task based exercises must be included in the syllabus. Since there is hardly an environment to target language, it is suggested that students must be sent on a tour to English speaking countries to have an exposure to target language.

Table 7. Results of interview question No. 5

\begin{tabular}{ccc}
\hline Q.5. & $\begin{array}{c}\text { Number of } \\
\text { participants }\end{array}$ & $\begin{array}{c}\text { Is the course designed in accordance to the learner- } \\
\text { based approach? Comment briefly! }\end{array}$ \\
\hline 18 & The course is learner centred. \\
02 & The course is not learner-centred. \\
\hline
\end{tabular}

As shown in Table 7, in response to question number 5, 18 teachers completely agreed that the course is learner-centred while the rest of 2 (a minority) teachers accepted that the course is not learnercentred. It shows that textbook is learnercentred and is doing well. There is hardly any need to replace it.

\section{CONCLUSION}

An overall analysis of teachers' questionnaire and interview result affirms that teachers are quite satisfied with the present syllabus. This book is in operation for last one year. Before this, teachers used to collect teaching materials from different resources, like internet. As a result, the materials lacked coherence and cohesion and course objectives were also partially fulfilled. The present syllabus is designed and textbook is selected after a careful introspection of course contents by a committee of experts of materials development in the university. Students also demonstrate a better progress than last few years. Therefore, the study wholeheartedly approves present syllabus and does not recommend replacing the textbook. However, teachers can exploit other resources (from internet or library) in order to give an extra push to their learners.

\section{REFERENCES}

Alderson, J. C. (1980). A process approach to reading at the University of Mexico: Projects in materials design. London: The British Council.

Altman, H. B., \& Cashin, W. E. (2003). Writing a syllabus. Retrieved from http://www.engineering.cornell.edu/academics/te aching/teaching_excellence/res ources/upload/AltmanSyllabus.pdf.

Ariffin, S. R., \& Salbiah, M. (1996). Pemikiran guru cemerlang: Kesan teradap prestasi pengajaran. Kertas kerja seminar isu-isu pendidikan Negara. Fakulti Pendidikan, Universiti Kebangsaan Malaysia, Bangi.

Berwick, R. (1989). Needs assessment in language programming: From theory to practice. In R. K. Johnson (Eds.), The second language curriculum. New York: Cambridge University Press.

Brindley, C. (1989). The role of needs analysis in adult ESL programme design. In R. K. Johnson (Eds.), The second language curriculum. New York: Cambridge University Press. 


\section{Soada Idris Khan}

An evaluation of technical report writing syllabus at the preparatory year program

Crocker, T. (1981). Scenes of endless science: ESP and education. London: The British Council

Davis, B. G. (1993). Tools for teaching. San Francisco: Jossey-Bass.

Eberly, M. B., Newton, S. E., \& Wiggins, R. (2001). The syllabus as a tool for studentcentered learning. Journal of General Education, 50(1), 56-74.

Grunert, J. (1997). The course syllabus: A learningcentered approach. Bolton, MA: Anker.

Harmer, J. (1991). The practice of English language teaching. London: Longman.

Hawkey, R. (1980). Syllabus design for specific purposes: Projects in materials design. London: The British Council.

Ismagilova, L. R., \& Polyakova, L. R. (2015). The role of course evaluation and needs analyses for syllabus design: An application to "English Language" course for master-degree students in economics. Mediterranean Journal of Social Sciences, 6(1S3), 346-351.

Jung, T., Osterwalder, H., \& Wipf, D. (2000). Teaching and assessing middle-year students' speaking and listening skill: Teaching and learning research exchange. Retrieved from: http://www.mcdowellfoundation.ca/main_mcdow ell/projects/research_rep/52_teaching_assessing. pdf.

McDonough, J. (1984). ESP in perspective: A practical guide. London: Jo McDonough.

McGrath, I. (2002). Materials evaluation and design for language teaching. Edinburgh.

Parkes, J., \& Harris, M. B. (2002). The purposes of a syllabus. College Teaching, 50 (2), 55-61.

Reed, V. (1989). Adolescent language disorders: General strategies for teaching language comprehension/listening. Eau Claire, WI: Thinking Publications.

Widdowson, H. G. (1983). Learning purpose and language use. New York: Oxford University Press.

Woolcock, M. J. V. (2003). Preparing a syllabus: Practical exercises. The Harriet W. Sheridan Center for Teaching and Learning Brown University. Retrieved from https://www.brown.edu/about/administration/sher idan-

center/sites/brown.edu.about.administration.sheri dancenter/files/uploads/ConstructingaSyllabus.pdf.

Yalden, J. (1987). Principles of course design for language teaching. Cambridge: Cambridge University Press. 